University for Business and Technology in Kosovo

UBT Knowledge Center

UBT International Conference

2017 UBT International Conference

Oct 27th, 1:00 PM - 2:30 PM

\title{
Challenges and prospects of hydropower options in Albiana. Can Albania lead the region.
}

\author{
Ermela Dërmyshi \\ Local Web Srl Albania, ermeladermyshi@gmail.com \\ Xhonsila Hoxha \\ General Directorate of State Enforcemant Service Albania, hoxha.xhonsila@hotmail.com
}

Follow this and additional works at: https://knowledgecenter.ubt-uni.net/conference

Part of the Business Commons

\section{Recommended Citation}

Dërmyshi, Ermela and Hoxha, Xhonsila, "Challenges and prospects of hydropower options in Albiana. Can Albania lead the region." (2017). UBT International Conference. 238.

https://knowledgecenter.ubt-uni.net/conference/2017/all-events/238

This Event is brought to you for free and open access by the Publication and Journals at UBT Knowledge Center. It has been accepted for inclusion in UBT International Conference by an authorized administrator of UBT Knowledge Center. For more information, please contact knowledge.center@ubt-uni.net. 


\title{
Challenges and prospects of hydropower options in Albiana. Can Albania lead the region.
}

\author{
Ermela Dërmyshi ${ }^{1}$, Xhonsila Hoxha ${ }^{2}$, \\ ${ }^{1}$ Local Web Srl Albania, \\ ermeladermyshi@gmail.com \\ ${ }^{2}$ General Directorate of State Enforcemant Service Albania, \\ hoxha.xhonsila@hotmail.com
}

\begin{abstract}
With world electricity demand increasing, exploitation of the considerable potential for hydropower generation in many developing countries is an attractive prospect. Even Albania looks to have a high potential in this sector. In general, electricity generation in Albania mainly depends on hydropower, as about $90 \%$ of electricity is generated by it. For this reason, we aim to identify and explore challenges and prospects of hydropower sector in our country regarding the economic and social aspects. Also, is important to see if Albania can be the leader of the Western Balkans. To get the results we used secondary data, collected from different reports and publications. This study shows us that Albania, despite of non-favorable political and technology developments, has done a big step to create a stable source of energy. This thing impacts economic growth in the long-run.
\end{abstract}

Keywords: Hydropower, Albania, Western Balkans, Prosperity, Development

\section{Introduction}

Albania is in south-western part of Balkans peninsula, Southeast Europe. The country is linked with the rest of the world via land, sea and air routes. The highest peaks are those in the Alps and the Eastern Mountains (Korabi $2751 \mathrm{~m}$ ) and the lowest peaks are in the western coast area. The landscape is intersected by the valleys of Vjosa, Devoll, Osum, Shkumbin, Erzen, Mat and Drin rivers, eastward and westward, which enable the connection of Adriatic Sea with the internalpart of the country and the Balkans.

After Albania emerged from 50 years of communist rule, the transition from a centrally planned to a market-oriented economy, together with abundant international aid and other strategic assistance helped the country make progress. Thanks to strong growth performance, Albania grew from the poorest nation in Europe in the early 1990s to middle-income status in 2008, with poverty declining by half during that period. Albania's economic transformation continues to build upon its huge potential. However, the global financial crisis exposed the weaknesses of its growth model and highlighted the need to shift from consumption-fueled to investment- and export-led growth. Albania has a population of 2.9 million. GDP per capita is 4,129 USD in 2016 and the economic growth for this year is $3.4 \%$. The annual variation of investment is $7.7 \%$.

Through years, water has played an important role in human history, since it is a vital resource. Water has been used for different purposes, this starting from the use of water as a source of human life furthermore water is used as a source of energy. Hydropower is renewable, reliable, nonpolluting source of energy that comes from natural flow of water. 


\section{Hydropower in Albania}

Albanian hydrographical territory is $44,000 \mathrm{~m}^{2}$ or $57 \%$ larger than its geographical territory. The average altitude of the hydrographical territory is about $700 \mathrm{~m}$ above the sea level. The total average flow of the rivers is about $1245 \mathrm{~m} 3 / \mathrm{sec}$. Due to the morphological features, Albania is quite rich in rivers, with more than 152 rivers and torrents forming eight big rivers. They have a southeast-northwest flow, mainly oriented towards the Adriatic coast. The most important rivers are: Drin with $340 \mathrm{~m} 3 / \mathrm{sec}$, Vjosa with $210 \mathrm{~m} 3 / \mathrm{sec}$, Seman with $101 \mathrm{~m} 3 / \mathrm{sec}$, Mat with $74 \mathrm{~m} 3 / \mathrm{sec}$, Shkumbin with $60 \mathrm{~m} 3 / \mathrm{sec}$, etc. Although with small flows, their considerable cascade makes these rivers substantially important for the hydropower potential offered to the country. Consequently, Albania is a country rich in water reserves and a hydropower potential that bears an important developmental role for the country. The Drin river, located in northern Albania, is the largest river in the country and hosts three hydropower stations: Fierzë (500 MW), Komani (600 MW) and Vau i Dejës (250 MW). This 1,350 MW cascade represents more than threequarters of the country's total electricity capacity and 90 per cent of domestic electricity production. The remaining $430 \mathrm{MW}$ of installed capacity is distributed over some 90 stations (Association, 2015). While efforts to develop new thermal, wind and solar capacity are ongoing, hydropower remains the nation's largest energy resource. Estimates show that only 30 to 35 per cent of Albania's hydropower potential has been developed so far (Association, 2015). Delays due to social and environmental concerns have been a deterrent to major projects. Instead, the government has focused on constructing smaller hydropower plants (less than $100 \mathrm{MW}$ capacity) and passing fiscal incentives. For example, investments in renewable energy sources are exempt from customs duties on imported machinery and equipment. Due to these favourable legal and regulatory frameworks, Albania's hydropower sector remains attractive to foreign and private investors.

Albania's mid-term goal is to once again become a net importer of electricity by developing its significant hydropower potential. In this way, Albania could increase its influence in the regional energy market while simultaneously bolstering its own energy security. For example, in 2014, Albania and Kosovo signed an agreement to build a $400 \mathrm{KV}$ transmission line linking their energy grids to maximise Albania's hydropower and Kosovo's coal-fired electricity. In July 2015, the EU announced funding for another $400 \mathrm{KV}$ interconnection line between Albania and Macedonia. Albania is also exploring options for an undersea electricity interconnection to export excess power to Italy. (Association, 2015)

Building HEC-es in Albania can make it a "super power" regional energy provider, as it is pretended, but with no doubt this thing will cause high costs for it in the long run. According to a study made from Ulrih Zhvarc, the deformation of the rivers' flow with the building of many hydropowers in one cascade will bring big conequenses for Albania. Albanian Riviere risks to have changes, which are not in favour of tourism. These hydropowers also attack the ecology. This will cause damages in the ecosystem.

Albania has a huge hydropower potential and only $35 \%$ of this potential is used. There is still place for further development. The total hydropower reserves allow the instalation of 4500MW. Since 1997 to 2015, 171 concession agreements have been signed for the construction of 502 HPP across the country, with an Installed capacity of $2113 \mathrm{MWh}$, expected annual output of 9121 GWh and with contracted investment value 314059 (Lek million). 
Table 1. Hydropower potential

\begin{tabular}{|l|l|}
\hline Total installed capacity & $1878 \mathrm{MW}$ \\
\hline Potential installed capacity & $4500 \mathrm{MW}$ \\
\hline Average power production & $4,2 \mathrm{TWh}$ \\
\hline Potential annual power production & $16-18 \mathrm{TWh}$ \\
\hline Hydroelectric energy potential utilized & $35 \%$ \\
\hline
\end{tabular}

Source: Ministry of Energy, ERE

The companies which operate 101 HEC that have had a contract with KESH/FPSH have a total instaled power of 342.2 MW. The total net output in 2015 from concessions was $1413709 \mathrm{MWh}$ (24.1\% of total net output in 2015). According to the declarations from the participants of the market, based on historik data, considering also the potential growth and non technical loss reduction, has been accepted that the excepted growth that will be transmeted from OST will be 1.5-2\%. The table below has data for electric energy purchased and selled in 2015 and 2016 according to financial statemants of OSSHE. As we see it, in 2016 Albania has decreased the purchasings and increased the sellings of energy. Also the loss is less in 2016 than in 2015.

Table 2: Statemant of Rewenues and Spendings 9-months

\begin{tabular}{|l|l|l|l|}
\hline Description & $\begin{array}{l}\text { Realisation } \\
\text { September 2015 }\end{array}$ & $\begin{array}{l}\text { Realisation } \\
\text { September 2016 }\end{array}$ & Differences \\
\hline Energy purchased & $4,390,577$ & $4,239,544$ & $(151,034)$ \\
\hline Energy selled & $2,997,979$ & $3,046,748$ & 48,770 \\
\hline Loss \% & $31.72 \%$ & $28.13 \%$ & $3.58 \%$ \\
\hline
\end{tabular}

Source: OSSHE

According OST's data and the realisation of 2014 and 2015, is made a prediction of electricity energy's demand, its coverage from domestic production and import in five future years.

Table 3: The prediction of the demand for electric energy, domestic production and import in five years

\begin{tabular}{|l|l|l|l|l|l|}
\hline Year & 2016 & 2017 & 2018 & 2019 & 2020 \\
\hline $\begin{array}{l}\text { The demand of } \\
\text { electric energy } \\
\text { (GWh) }\end{array}$ & 6905 & 7010 & 7094 & 7238 & 7348 \\
\hline $\begin{array}{l}\text { Domestic } \\
\text { Production } \\
\text { (GWh) }\end{array}$ & 4620 & 4740 & 4826 & 4973 & 5103 \\
\hline Importi (GWh) & 2285 & 2270 & 2268 & 2265 & 2245 \\
\hline
\end{tabular}

Source: Ministry of Economy and Energy, 2016 
According to the prediction, Albania will have an increase of energy demand but it will be covered more from domestic production. Imports will be less. This is because of new capacitys of production, new hydropowers and new technology, also a better managemant of losses.

The large financial imbalances of energy SOEs threaten Albania's fiscal stability and absorb an increasing share of its resources. Since 2014, the government has pursued a program to invest in new small-scale generating plants, reduce distribution losses, raise tariffs to cost-recovery levels and open the Albanian electricity market to regional competition.

\section{Literature review}

Over the last two decades, global electricity production has more than doubled, and electricity demand is rising rapidly around the world as economic development spreads to emerging economies. Therefore, technical, economic and environmental benefits of hydroelectric power make it an important contributor to the future world energy mix, particularly in the developing countries. In addition, small hydropower (SHP) represents an alternative to fossil fuel generation and does not contribute to either greenhouse gas emissions or other atmospheric pollutants. However, developing the remaining hydropower potential offers many challenges, and pressures from some environmental action groups over its impact has tended to increase over time. Hydropower throughout the world provides $17 \%$ of our electricity from an installed capacity of some $730 \mathrm{GW}$ is currently under construction, making hydropower by far the most important renewable energy for electrical power production. The contribution of SHP to the worldwide electrical capacity is more of a similar scale to the other renewable energy sources ( $1-2 \%$ of total capacity), amounting to about $47 \mathrm{GW}(53 \%)$ of this capacity in developing countries (Yuksel). A study held in United States assumes that real output and employment are long run forcing variables for nearly all measures of disaggregate energy consumption. To have the results they have used the autoregressive distributed lag (ARDL) approach developed by Pesaran and Pesaran [Pesaran, M.H., Pesaran, B., 1997. Working with Microfit 4.0. Camfit Data Ltd, Cambridge] and Pesaran, Shin and Smith [Pesaran, M.H., Shin, Y., Smith, R.J., 2001. They focused their attention on the following energy consumption variables: coal, fossil fuels, conventional hydroelectric power, solar energy, wind energy, natural gas, wood, and waste. The sample period covers 2001:1-2005:6 (Sari \& Bradely). "The conversion of energy is directly related to the pollution in terms of greenhouse gas emission caused by the power plants" says a study about the role of renewable energy in sustainable development. The major greenhouse gases like carbon dioxide and carbon monoxide are causing global warming to the environment and hence there is a need to find out alternatives to produce energy in an environmentally benign way. (Joshi, Dincer, \& Reddy). A paper made from researchers in Bhutan highlights the role and importance of hydropower for social and economic development of Bhutan and covers aspects related to planning and policy initiatives being pursued by the Hydropower sector to fulfill the national objectives. (Tshering \& Tamang). An interesting study is held in UK from Arthur Williams and Stephen Porter. This study gives the conclusion that investment is recouped 25\% more quickly where many very small hydro schemes are used instead of one large scheme, but the level of investment required for the single scheme is far greater. Based upon these results, the applicability of hydro projects utilizing schemes of different sizes is discussed. (Williams \& Porter). Another study is made in Brazil which investigates the causal relationship between clean and non-clean energy consumption and economic growth over the period of 1980-2009. The results from error correction model reveal the interdependencies between new renewables, nuclear, fossil fuel, and total non-renewable energy consumption and economic growth, the unidirectional causality from hydroelectric/total renewable consumption to economic growth, the substitutability between new renewables and fossil fuel consumption, and the substitutability between new renewables and nuclear energy consumption. Overall, aggregated analysis may 
obscure the relationship between different types of clean energy consumption and economic growth (TienPao \& ChiaFu).

\section{Albania and the Western Balkan countries.}

The six countries of South East Europe, Albania, Bosnia and Herzegovina, Kosovo, FYR Macedonia, Montenegro, and Serbia, must operate within a complicated global environment. Political, institutional, and policy uncertainty in advanced economies, still low commodity prices, and exceptionally low interest rates dampen global growth expectations. Growth is slow everywhere, and the European Union (EU), a major destination for SEE6 exports, this year is estimated to grow 1.9 percent, even less than last year's 2 percent.

Within the six countries of the Western Balkans energy efficiency (EE) is increasingly seen as a key pillar in national energy strategies, helping to enhance energy security, contribute to economic growth, and ensure environmental sustainability. This is for several reasons. EE can reduce the region's heavy reliance on expensive imports, enhance competitiveness and job creation, and reduce the impact of widespread fossil fuel use. EE can also bring important social benefits, helping to improve local air quality (mitigating related adverse health impacts), improve indoor comfort levels through improved heating, and make energy more affordable for lowincome families. To realize these benefits, the Western Balkans countries will have to shift from broad policies and small-scale pilots to scaled-up financing and implementation.

The Western Balkan region has the largest remaining unexploited hydropower potential in Europe as its river catchments have remained largely undeveloped. Up to 30 per cent of rivers remain in near-natural or pristine states and have a very high conservation value. The region has an estimated $80,000 \mathrm{GWh}$ technical potential, which is concentrated in the mountainous regions of Montenegro and Albania. The main domestic sources of electricity generation in the region are coal and hydropower. Albania derives 98 per cent of its domestically produced electricity from hydropower, Bosnia and Herzegovina 41 per cent, Serbia 30 per cent and Montenegro 31 per cent.

Serbia has the highest installed hydropower capacity in the region, with some 2,835 MW currently operational. Over two-thirds of this capacity is concentrated near to the border with Romania, which hosts the Iron Gate 1 and 2 stations (2,116 MW and $540 \mathrm{MW}$ respectively), which are shared equally with Romania. The country boasts an undeveloped potential of 7,000 GWh, focused on the Drina and Danube rivers. With financial assistance from the European Bank for Reconstruction and Development (EBRD), Serbia announced plans to install new hydropower plants and two existing dams, and to rehabilitate a further 15 existing power plants totaling around $30 \mathrm{MW}$. With increased projected solar PV and wind penetration, Serbia has identified the essential need for a further pumped storage station, potentially the 680 MW Bistrica or 1200 MW Iron Gate 3 (IHA, 2016).

Bosnia and Herzegovina has a hydropower potential of more than 6,000 MW, of which only 2,504 MW is currently exploited. In 2015, the country commissioned a 5.2 MW hydropower plant in Rogatica in the Republika Srpska region. The Republika Srpska also signed a memorandum of understanding (MOU) with the China International Water \& Electric Corporation (CWE) for the development of the $160 \mathrm{MW}$ Dabar project in the south. This project is expected to improve generation at downstream stations, and provide flood protection and irrigation services. However, the project has met strong opposition due to the water transfer away from the Neretva catchment and associated ecosystem damages. The country, in its in its intended nationally determined contribution (INDC), also announced plans to commission a further 120 MW of small-hydro plants (<10 MW) by 2030.

Macedonia has a technical hydropower potential of 5,500 GWh, of which only about 1,500 GWh is currently utilized, representing a total installed capacity of 674 MW. Most of its currently operational stations are in the mountainous north-west, near to the Albanian border. The country 
officially opened five small hydro plants in 2015 located in Kavardarci in the Tikveš region. The project includes an irrigation system on the Bosava River. The five power plants of the Kolektor Cascade Range in capacity from 1.4-2.8 MW and total 10.9 MW.

Kosovo currently relies almost exclusively on two coal power plants for over 97 per cent of its power generation, and the system is marred by high technical and commercial losses. With the planned closure of one of the coal power plants in 2017, the country faces peak capacity gaps, which are required to be met through expensive imports. There are plans, however, to augment power supply through the construction of an aggregated $63 \mathrm{MW}$ of small-scale, run-of-river projects across the country, while the Energy Regulatory Office of Kosovo plans some $140 \mathrm{MW}$ by 2020. Kosovo's long-term energy strategy also includes the 305 MW Zhur station which will provide peaking support to accommodate variability in the grid.

Montenegro has abundant water resources, despite its relatively small size. Two large hydropower plants, Perućica (307 MW) and Piva (363 MW) provide for approximately threequarters of domestic power supply, but account for only 18 per cent of total hydropower potential. There are currently 27 projects being implemented on some 25 water courses, totalling $83 \mathrm{MW}$. The country also signed an MOU with Norinco International Corporation Ltd, a Chinese Company, to explore the possibility of developing four hydropower plants on the river Morača with a combined installed capacity of $238 \mathrm{MW}$.

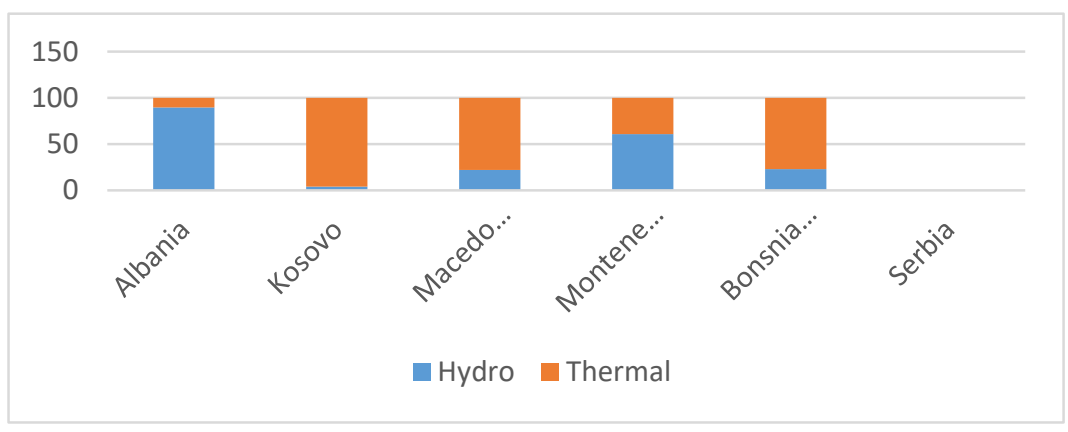

Fig. 1. Generation Structure (Damir Pesut, Croatia)

In the generation structure Albania is almost totally depended in hydro energy. Other countries have more dependence in thermal hydro (accepting Montenegro which has more hydro energy in its generation structure, but it is less than for Albania) (Pesut). This high percentage is bad for the country itself but is good for the development in the region. For the country it may bring problems for not diversifying. If a problem happens in this sector will cause high consequences for the state. But, if we see it compared to other countries in the region, we can see it as an opportunity also. The fact that Albania has a higher percentage of hydro energy usage shows that Albania has highest opportunities to lead the region in this sector. All the investments for energy in Albania are made in hydro power, so this sector will be more developed than in the other countries which invest in different sectors in a while.

In the Southern Europe region, where Albania is part of, the overall installed capacity of hydropower is $6286 \mathrm{MW}$ while the estimated potential is $16310 \mathrm{MW}$. This indicates that approximately $39 \%$ must be developed. The region has a significant amount of untapped small hydropower potential, estimated to be at least $16 \mathrm{GW}$, as well as other renewable energy sources. To promote the development of renewable energy, all countries of the region have implemented economic incentives. Southern Europe still faces a few barriers when it comes to developing the small hydropower sector, mainly due to the long and complicated authorization and licensing process. Other institutional and regulatory barriers include corruption, disagreement between local and national regulations, and even frequent changes in small hydropower regulations (UNIDO, 2016). 
To speed up the process, governments will have to adopt decisions that will remove the remaining blocking points, as well as to step up regional cooperation of both Western Balkan 6 parties and EU Member States towards an efficient integration of their day-ahead and balancing markets (ECS).

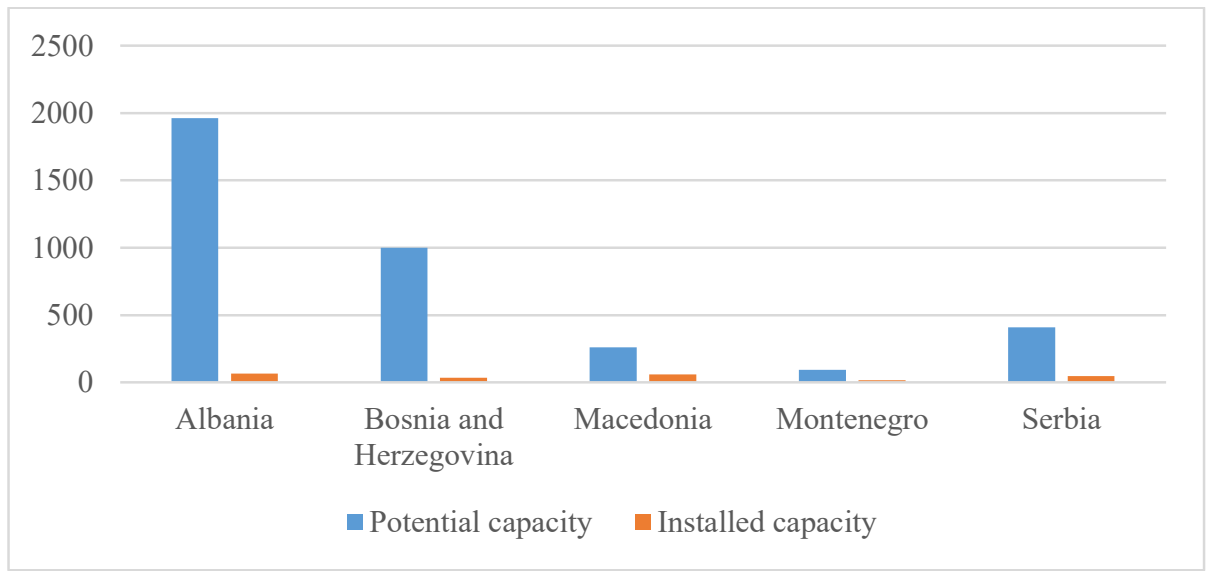

Fig. 2. Small hydropower capacity in Western Balkans (UNIDO 2016)

As we see from the graphic above, we notice that Albania has the highest potential capacity in small hydropower compared to the regional states. Albania has used $3.3 \%$ of its capacity, Bosnia and Herzegovina 3.6\%, Macedonia 23\%, Macedonia 19\% and Serbia 11\%. This is a good indicator for the future of Albania, if the politics and investments go in the right way and are supporters of this development.

\section{Conclusions}

Hydropower is renewable, reliable, nonpolluting source of energy that comes from natural flow of water. Albania has a high potential of developing in this sector. Its mid-term goal is to once again become a net importer of electricity by developing its significant hydropower potential. In this way, Albania could increase its influence in the regional energy market while simultaneously bolstering its own energy security. And the future seems good to Albania. According to reports, studies and datas compared to the other countries of the region, it has a potential to be one of the leaders of this sector in Western Balkans. Albania has the bigest potential capacity from all other countries of the region. And only a few of this potential is used. It also has used all its investment in energy for hydro power. One of the stronger points, which make Albania a potential to lead the regional market, is its hydrographical territory, aboundand in rivers. In the last years many investment are made in this sector which bring hydro power in Albania in another level. The state is also a supportet. With this good opportunities and good developments, Albania can some day be a leader in hydropower sector in Western Balkans. 


\section{References}

1. Association, I. H. (2015). Hydropower Status Report.

2. ECS. (n.d.). 6 Western Balkans Report.

3. IHA. (2016). Western Balkans.

4. Joshi, A., Dincer, I., \& Reddy, B. (n.d.). Role of Renewable Energy in Sustaniable Development.

5. Pesut, D. (n.d.). Overview of energy sector in Balkan Region. Croatia.

6. Sari, R., \& Bradely, E. (n.d.). The relationship between disaggregate energy consumption and industrial production in US.

7. TienPao, H., \& ChiaFu, H. (n.d.). The casual relationship between energy resources and economic growth in Brazil.

8. Tshering, S., \& Tamang, B. (n.d.). Hydropower-Key to sustainable, socio-ecocomic development of Bhutan.

9. UNIDO. (2016). World Small Power Development Report.

10. Williams, A., \& Porter, S. (n.d.). Comparsion of hydropower options for developing countries with regard to the environmental, social and economic aspects.

11. Yuksel, I. (n.d.). Development of Hydropower: A case Study in Developing Countries. 